\title{
Knowledge and attitude of postnatal mothers towards neonatal care in a rural area of Maharashtra, India
}

\author{
Shilpa Chaudhari $^{1 *}$, Smritee Virmani ${ }^{2}$
}

\begin{abstract}
${ }^{1}$ Professor in Department of Obstetrics and Gynecology, Smt. Kashibai Navle Medical College and General Hospital, Pune, India,

${ }^{2}$ Assistant professor in Department of Obstetrics and Gynecology, Smt. Kashibai Navle Medical College and General Hospital, Pune, India
\end{abstract}

Received: 09 April 2016

Revised: 07 May 2016

Accepted: 10 May 2016

\section{*Correspondence:}

Dr. Shilpa Chaudhari,

E-mail: drshilpachaudhari@yahoo.com

Copyright: $\odot$ the author(s), publisher and licensee Medip Academy. This is an open-access article distributed under the terms of the Creative Commons Attribution Non-Commercial License, which permits unrestricted non-commercial use, distribution, and reproduction in any medium, provided the original work is properly cited.

\section{ABSTRACT}

Background: The neonatal period encompassing the first 28 days of extra uterine life is the most crucial time in baby's life. It is an important link in the chain of events from conception to childhood. The mother's or caregivers' past experiences and knowledge play an important role in safeguarding the new-born's health and enhancing adaptation to the new environment.

Methods: A community based cross sectional study was carried out in the rural area of Pune district for 2 months period. Thirty postnatal mothers within 28 days of delivery were given semi-structured questionnaire to assess neonatal rearing practices amongst them.

Results: Seventeen percent mothers initiated breast feeding within one hour of delivery, $15 \%$ after two days while $33 \%$ did not give colostrum to the baby. Thirty seven percent women gave no prelacteal feeds. Eighty seven percent gave zero polio doses to their baby. Sixty three percent bathed the baby by day two while $11 \%$ bathed as late as after 30 days. Ninety seven percent gave sesame seed oil massage to the baby.

Conclusions: Most mothers had good practices even though the beliefs were different. Awareness of the need to initiate breast feeding within one hour and to continue it during baby's illness and need for exclusive breast feeding for first six months is essential.

Keywords: Rearing practices, Postnatal mother, Neonatal period

\section{INTRODUCTION}

Neonatal period encompasses the first 28 days of extra uterine life and it is the most crucial time in baby's life. The mother's or caregivers' past experiences and knowledge play a crucial role in safeguarding health and enhancing the new-born's adaptation to the new environment. ${ }^{1}$ This period is an important link in the chain of events from conception to adulthood. The physical and mental wellbeing of an individual depends on the correct management of events in the perinatal period. $^{2}$
Every year, around 2.5 million babies are born in India accounting for fifty births every minute. According to National Family Health Survey-3, only $31.1 \%$ births in rural India are institutional and the rest being conducted at home by trained birth attendants. ${ }^{3}$ Most mothers (at least two thirds) are illiterate with no knowledge or information regarding mother craft and have hardly any say in society. The situation is worse in rural areas. Significant improvement in national perinatal health indices and survival of new-born babies can thus only be achieved when essential health care facilities are made available to all mothers and their babies in the community throughout the country. ${ }^{4}$ 
Child birth is a time of transition and social celebration in many societies, signalling an adjustment of cultural responsibilities. In some societies, there is a continuum between traditional and modern care, with some households operating at the traditional end, while others at the modern end, with the majority somewhere in between. $^{5}$

Internationally many studies describe the traditional beliefs and practices surrounding childbearing. Some traditional practices are beneficial to the mother and baby, whereas others are not. Certain practices immediately following delivery can contribute to newborn mortality and morbidity, but a package of essential new-born practices has proven to reduce these risks. The time around childbirth is culturally very important and existing behaviours are commonly rooted in traditional beliefs. $^{6}$

Children constitute the foundation of the nation. Healthy children evolve to become healthy adults and effectively participate in national development. Each new-born is perceived as a precious addition to the family. Hence, care of each new-born is important. Wrong practice of new-born care is one of the most important causes of neonatal deaths. Therefore, there is a need to improve home based primary new-born care in order to enable mother to ensure health of new-borns. ${ }^{7}$

Care and nursing of new-born becomes the primary responsibility of the parents especially the mother. One of the most crucial needs often felt by the new born parents is about their sense of insufficient knowledge. The inherent need to learn more about the care of new-born motivates the mother to learn from the environment, family members and health personnels. ${ }^{8}$

In India the current status of indicators such as infant mortality rate and neonatal mortality rate are 43.8/1000 and $30.9 / 1000$ live births respectively. ${ }^{9}$ An understanding of new-born care in home environment is therefore essential for effective behavioural change strategies to be developed. Keeping this view in mind the present study was conducted to explore the local new-born care and identify practices which are harmful and beneficial to the new-borns.

\section{METHODS}

A community based cross sectional study was conducted for 2 months period in a rural area of Pune district, Maharashtra amongst a group of 30 mothers by snowball sampling technique. Postnatal mothers within 28 days of delivery were selected and data was collected using open ended semi-structured questionnaire. The following tools were included: maternal dietary practices, breast feeding practices, prelacteal feeds, new-born care practices, practices during neonatal sickness, immunisation of neonate and beliefs directed practices. After obtaining a written consent from the mothers, questionnaire was given and confidentiality ensured. Time taken for each mother was $30-40$ minutes.

\section{RESULTS}

\section{Demographic profile}

Forty percent mothers were of the age group of 21-25 years. Fifty percent had secondary education while $7 \%$ were illiterate. Sixty percent mothers were multiparous, $83 \%$ had normal vaginal delivery out of which $72 \%$ were hospital deliveries and $28 \%$ were home deliveries conducted by either dai, mother or mother in law (Figure 1). Ninety percent had social support from husband and in laws and $60 \%$ resided in joint family.

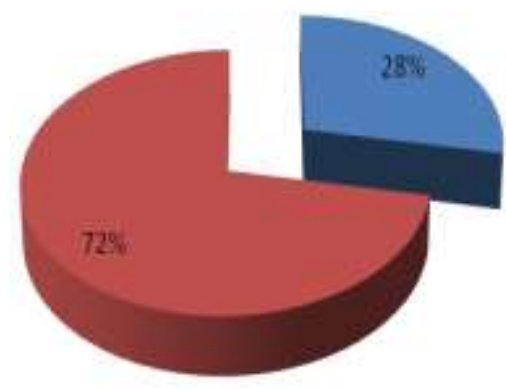

\$ Home deliveries

Hospital deliveries

Figure 1: Distribution of mothers according to place of delivery.

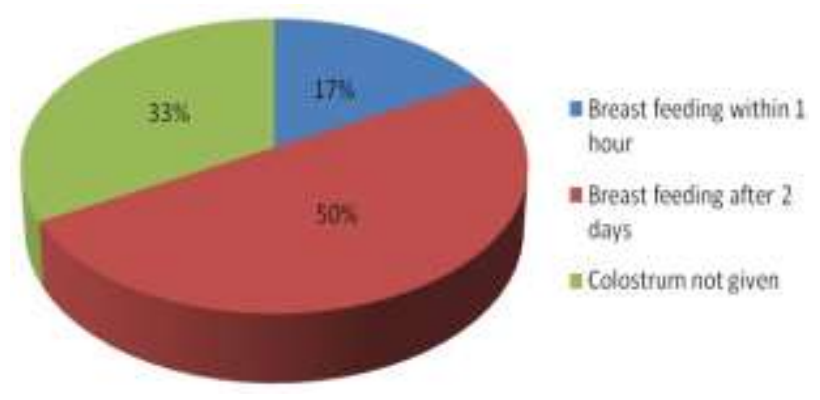

Figure 2: Breast feeding practices.

\section{Beliefs and practices}

\section{Mother's dietary practices}

Forty seven percent mothers had iron and protein rich diet in the antenatal period. In addition they also had fruits, coconut water and milk while in the postnatal period $77 \%$ had a high protein diet in the form of cereals, special ladoos, milk and ghee.

\section{Breast feeding practices}

Only $17 \%$ mothers' initiated breast feeding within one hour of delivery following instructions of the health care professionals, however $50 \%$ initiated after 2 days as milk production was not there and the mother was too tired while the remaining $33 \%$ did not give colostrum to the 
baby as they believed that colostrum was not good for the baby (Figure 2). Seventy three percent mothers breastfed their babies in sitting position with the belief that keeping baby's head on mother's palm gave round shape to the head, helped in feeding comfortably, provided support to mother's back and prevented aspiration. Thirty seven percent mothers gave no prelacteal feeds (water, honey, coconut water, goat milk or lactogen) to the new born. All mothers breastfed from both breasts, 97\% breast fed from first breast completely before feeding from the other breast.

\section{New-born care practices}

Sixty three percent bathed the baby by $2^{\text {nd }}$ day and thereafter daily as they believed that bathing keeps baby's body clean and prevents infection while $11 \%$ bathed their babies as late as 30 days after birth. Ninety seven percent mothers gave sesame seed oil massage and also applied it to baby's skull bones as they believed that it was useful for baby's skin, keeps the body clean, helps in weight gain, strengthens baby's bones and prevents common cold to baby. Massage was either given by mother, mother in law or dais. Eighty percent gave ayurvedic smoke to babies as it was a traditional belief of elders. Ninety seven percent mothers swaddled their babies with the belief that it kept the baby warm, comfortable, helped the baby to sleep well and prevented the baby from getting cold. All mothers dressed their babies in soft cotton clothes as per traditional belief. Eighty three percent babies slept with the mothers while the rest slept in a cradle.

\section{Practices during neonatal sickness}

All mothers reported that when baby was sick it cried, refused feeds, was warm to touch and did not sleep well. Eighty percent mothers continued to breast feed during baby's illness while others gave cow's milk.

\section{Neonatal immunization}

Only $87 \%$ mothers gave zero polio doses to the baby, those babies born at home were also immunised.

\section{Belief directed practices}

Eighty percent mothers believed that their babies should be protected from evil. These beliefs were of the elders, family members, mother her or followed from generation to generation. In order to ward off evil $90 \%$ mothers applied a black dot of kajal on baby's forehead or foot. They also tied black thread around baby's neck, planned to shave baby's scalp by end of one month, did not give baby to strangers, did not travel with baby far from home, held either salt, chilly, broom, spoon in hand and made a circular motion around baby's head and threw it in fire to ward off evil. They also kept articles made of iron and leather under new-born's bed to thwart the evil eye.

\section{DISCUSSION}

Some practices and beliefs in the study were either beneficial or had no effect on maternal and neonatal health. Adherence to practices was based on past experiences of mother herself, mother in law and elders in the family. In the present study practices like mothers diet, new born care, belief directed practices were satisfactory. However an important neonatal rearing practice of initiation of breast feeding within one hour of birth was observed only in $17 \%$ of mothers which is quite low in comparison to National Family Health Survey-3 (NFHS-3) according to which the achievement is $21.5 \%$ in India and $53 \%$ in Maharashtra. ${ }^{3}$ As per District Level Household and Facility Survey (DLHS) in rural India $39.8 \%$ mothers initiate breast feeding within one hour. ${ }^{10}$ Twenty two percent neonatal deaths could be prevented if all mothers initiate breast feeding within one hour of birth. ${ }^{11}$ Another important issue regarding breast feeding is to feed colostrums to new-born. In our study $33 \%$ mothers did not give colostrum to the baby. Also prelacteal were not given by $37 \%$ women which in comparison to NHFS-3 report is less, according to it no prelacteal feed achievement is $43 \%$. $^{3}$ In our study only $87 \%$ mothers gave zero polio dose to their babies. Hundred percent immunisation of the neonate for polio vaccine is a need of the hour.

\section{CONCLUSION}

Early initiation of breast feeding prevents disease in the neonate and reduces neonatal mortality rate. This can be done by community education with the help of health personnel's. Health education of mother along with elder female members in the family can also help to increase acceptance of colostrum in a positive way. Once importance of early initiation of breast feeding and providing colostrum to neonate is achieved successfully then ultimately achievement of no prelacteal feeds will be done. Knowledge regarding zero dose polio vaccine should also be increased by timely health education.

\section{Funding: No funding sources \\ Conflict of interest: None declared \\ Ethical approval: Not required}

\section{REFERENCES}

1. Ghai OP. Essential Pediatrics, CBS Publishers, New Delhi, 6th edition, 2008; pp. 169.

2. Singh M. Traditional and cultural practices for the care of new-born babies. In: Care of the new-born. 4th ed. New Delhi: Sagar publishers; 1997. pp. 142144.

3. National Fact Sheet India 2005-2006. National Family Health Survey 3 (NFHS-3) Ministry of Health and Family Welfare, Government of India. International institute for population studies, Mumbai, 2005-2006. Available at http://www.rchiips.org/NFHS/PDF/India.pdf. 
4. Wong D. Essential of Pediatric Nursing, 9th ed. Missouri: Mosby publications. 2000; pp. 144-45.

5. Bryce J, Boschi-Pinto C, Shibuya K, Black RE, WHO estimates causes of death in children. Lancet. 2005;365(9465):1147-52.

6. Dadhich JP, Paul V. State of India's New-borns Report. New Delhi: National Neonatology Forum and Saving New-born Lives/Save the Children; 2004.

7. Hyder A, Morrow R, Wali S, Mc Guckin J. Burden of disease for neonatal mortality in South Asia and Sub Saharan Africa. Washington,DC: Save the children federation-USA; 2001. pp. 1-93.

8. Lauderdale J. Childbearing and Transcultural nursing care issues. In: Andrews M, Boyle J, editors.
Transcultural concepts in nursing care. 3rd ed. Philadelphia: Lippincott; 1999. pp. 81-106.

9. UNICEF/WHO/The World Bank/UN Pop Div. Levels and trends in child mortality. Report 2013. Available at http://www.who.int/ maternal_child_adolescent/ epidemiology/ profiles/ neonatal_child/ind.pdf

10. State Fact sheet 2007-2008. District level household and facility survey (DLHS-3), 2007-2008. Available at: http://www.rchiips.org/state-fact-sheet-rch3.html

11. Dadhich JP, Agarwal RK. Main streaming early and exclusive breast feeding for improving child survival. Indian pediatr. 2009;46(1):11-7.

Cite this article as: Chaudhari S, Virmani S.

Knowledge and attitude of postnatal mothers towards neonatal care in a rural area of Maharashtra, India. Int J Reprod Contracept Obstet Gynecol 2016;5:1883-6. 